\title{
Monotonic Paradigmatic Schemata in Italian Verb Inflection ${ }^{(*)}$
}

\author{
Vito Pirrelli and Marco Battista \\ II, $(?-(N)$

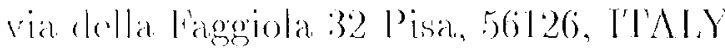 \\ \{vito,marco\}(itilc.pi.cor.it
}

\begin{abstract}
$\Lambda$ bstiract
In recent yours, morphological parakligmen have been tilue focus of an cxtonsive imvesti. gation, which has thrown in sharp redief the: descriptive adechacy of a paraclignt-biscel approach to the Morphology of lighly inflecting langlatges, with particulat emphasis

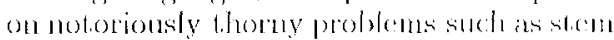

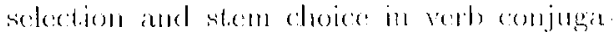

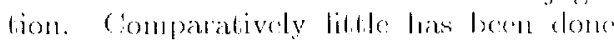

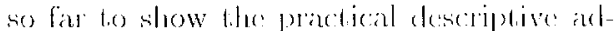
vantiages of ant extensive use of paracligms in a computational system for word analysis/generation. In this palser we report in some detail the results of a fully devel.

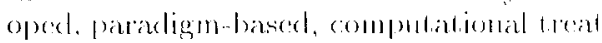
ment of the entine conjugational system of Italian. Wo focess on the comsiderable de-

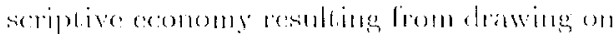

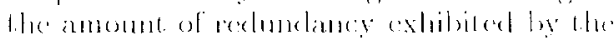

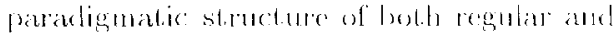

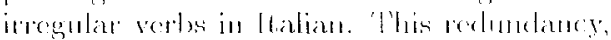
wo suggest, is captured thromgh sorealled pararligmatic sehemata. On implemen. lation compares favourably with ofther nonparadigmatic strategies in torms of both de. seriplive adecolatey and economy.
\end{abstract}

\section{Paradign-Morploology and Italian inflection}

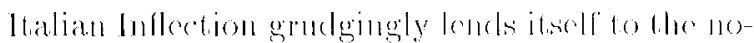
tion that Morphology is an inventory of itcus, called morphenues, eonsisting of and atsitrary association of a form (a contimusen phomologi.

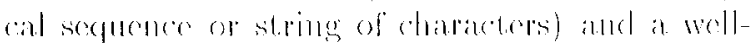

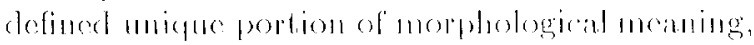
expressed through mopplusymlatedice and/or lexical

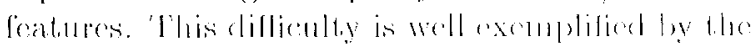

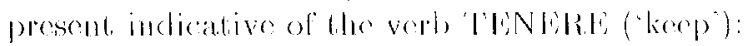

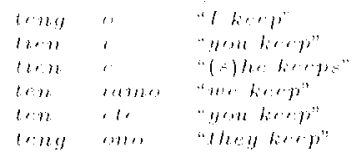

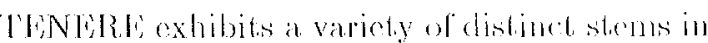

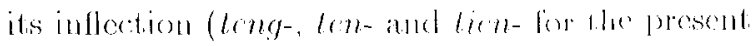

indicative only), cach of which can occur with particulan inflectional ondings and not with othcris. This property, which extends to all basic (i.e. non derivative and non inchontive) irregular ltalian verbs (abont 200 ) and has varionsly been chatacterised in the literature in terms of "receprocal ronditioning", "hederoedisin" and otherwise, rajses the issue of what regulare processe govertus stem selection. 'l'aditionally, reciprocal conclitioning has bern acconted for either as a phenomenon of eo-sedection between two independently iclentified morphological mits, or as a phonologinallygoverued alteration of the stem when in company of particular endings. With a good many verbs, andong which 'TENERE is a case in point, towever, the distributional difference between two stems and be infereed neither from any systematic difference in mophosyntactio feature content

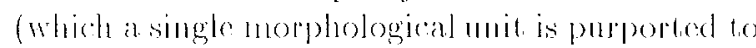
(onvey), nor from ordinary phonological ansider. ations. Paradigns offer an comomic and elegant way to capturo all these liactis.

\section{Stem Alternation and Choice}

In Morphology, a verb paradigm defines a sel of rells where fully inflected word forms are paired with a complete morphosyntiactic fouture speciliation feflecting the way relevant conjugintonal dimensions such as temse, mood, person. numbbere, and verb elass combine. Paradigms define a dimension of norphological andyesis which ruts across the spectermen of both tractitionial

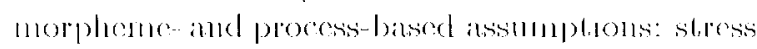
is haid on the way mophloological nocaning is nys-

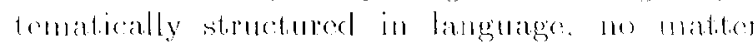
what formal means are put to 1 se to lill in a given

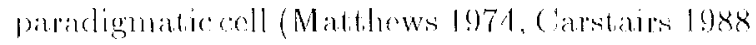
1992, Carstails and Stomberger los8. calder 1989, Stmml) 1961). For conventence, wo will here after assmono that llatian paradigmatio cells are filled in through a basically concalemative opera tion, trailing an inflectional encling alter a verb 
stem. lior a given verb class, ach inflectional ending presupposes and is presupposed by any other paradigmatically-related inflectional ending (Wurzel 1989). This is illustrated in the examples of the present indicative paradign of irregular Italian verbs given below, where a blank separatos the stem from the inflectional onding".

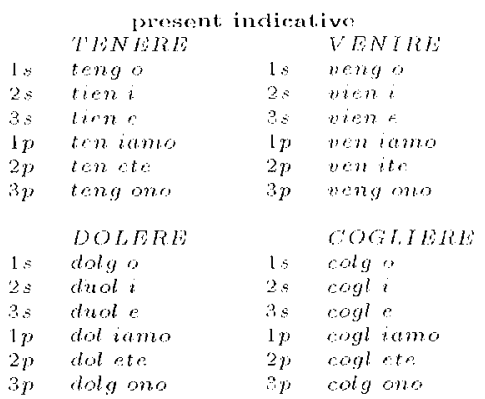

Besides the intralexemic character of Wurzel's presupposition relation paradigns also exhibit systematic interlexemic redundancios in stem selection (Pirrelli and Federici 1994). TTNERE and VISNTRE ("come), in spits of their belonging to different conjugational classes (respoctively second and third), exhibit an identical patitern of stem altomation, as illustrated in tho paradigmatic schema of gricl 1 below, where samencss of index expresses sameness of stem formation:
1)

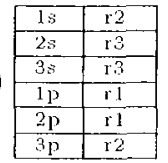

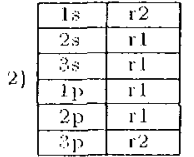

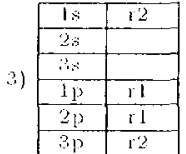

The grid is also applicable to the present indicalive of DOLIERE ('hurt') given above, independently of the substantial variation in phonological content between the stems of DOLERE and those of VENTRE and TENERE. When things are observed at the proposed level of abstraction, surprisingly few paradigmatic schmata, unspecified for phonological content and combined with appropriate conjugational classes of endiugs, suffice to generalize over the entiro Italian conjugation system (Spencer 1988, Pirrolli 1993).

There exists a direct relationship between the number of stem alternants of a verb and the paradigmatic schema the verb conforms to. Under the assumption that three stom altemants $r /$, r. and 13 are used for present indicative, they most often clistribute according to grid I above. Similarly, the present indicative of a two-stem verb rarely departs from grid 2 .

There is a nonempty intersection between schomata 1 and 2 (grid 3): a cortain amount,

${ }^{1}$ In the paradigm of cogliere the stem altemant cogl- is twrned into cogli- in the third-person singular and second-person plural of the present indicative by some separate readjustment rules. of combinatoric redundancy carries over from a three-stem paradigm to a two-stem paradigm. In particular, i) the same stem shows up in the firstperson singular and third-person plural, ii) $r /$ has the same distribution in the two schematia, iii) $r t$ occupies the slots left empty by the missing third stem alternant, so that the constraint that stem alternants in cells $2 s$ and 3 s are assigned the same index is not, violated. $\Lambda$ quick look at the paradigm of completely regular verbs (i.e. verlos with no stem alternation) confirms this trend: ro disappears, but its slots are taken over by r1. In a. nutshell, $r 1$ is the defanlt surface stem altemant and normally occupies slots which are left empty by nonexisting altermants.

The descriptive economy obtained by describing inflectional paradigns through paradigmatic schemata is considerable. Due to the distributional overlapping between three-stem paradigms and paradigms with fewer alternants, a single schema, specified for the maximum number of possibile stem alternants, suffices to account for the distribution of an entire class of verly alternantis, when the following simplified General Indexing Convention (GIO) is resorted to: a) assign the default index $r 1$ to the stem occurring in the cell of the second-person plural of present indicative; b) assign re to the stem of the first-porson singular of present indicative; c) assign r.3 to the stem of the second-person singular of present indicative.

In the following section we will detail a straightforward monotonic formalization of a), b) and c) in a typed featurc-structure formalism. Suffice it to say now that GTC makes reference to distitibutional properties only, specified in terms of the number of stem alternants that a lexeme exhibits. No mention is made either of the alteration which the stem undergoes or of the form of the corresponding inflectional ending. This is grounded on the Indexing Autonomy Hypothesis (AH), according to which "stem pairs exhibiting an identical contrast in formation needn't exhibit an identical contrast in indexing" (Stump 1995). $\Lambda \mathrm{t}$ first glance, the parallel distributional and formal behaviour of stem altemants in the present indicative of TWNERT and VENIRE secms to falsify IAII. Othor evidence, however, shows that IAII is indeed descriptively adequate. Consider, for concreteness, the alternation in stem pairs such as crocifigg-ete ('you crucify')/ crocifiss- $i$ ('I crucificd'), infligg-ete ('you inflict')/ infliss-i ('I iuflicted'). In spite of their similarity in stem formation, matched by partial distributional redundancies, any direct correlation between phonolog- 
ieal and clistributional regularities would lead to incorect paradignatice statements, as shown by the contrast between the past participle erocifiss-

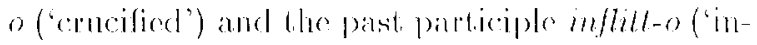
flicted') where yet whother stent altremant shows

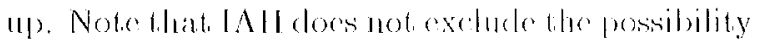
that a direet, correlation between form and indexing an be shipulated conventently. A more highly

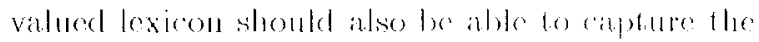
striking sintarily betwen the present indicative of both 'TlENBRE and VENTRE shown above. We will consider this possibility in the final part of the pilper.

\section{An AlEP Implementation}

Wo illustrate here a formalization of the paraligntbased model ontlined above, conched in the lyped-

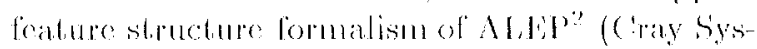
toms 1994, Battistal and Pirrolli 1995, Batidista ot a.1. 1995$)$.

bollowing Stump) (1995), a paradigm-basod treatment of thatian verb inflection repuires at least thees logically distinct typer ol lormal do vices: a) worct-fomation rules; b) paradigmatic sehemala, which select diflorenty indexed stem altermantis depencling on paradigmal.je distribution;

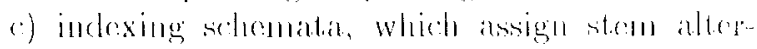

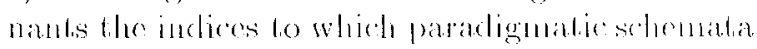
are sensitive.

We avail ourselves of a single worel-fomalion

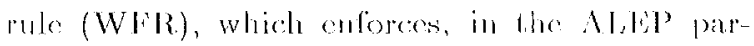
lance, morphotactic constatints on the compatibility of a stem and inflectional conding in an inflectied form:

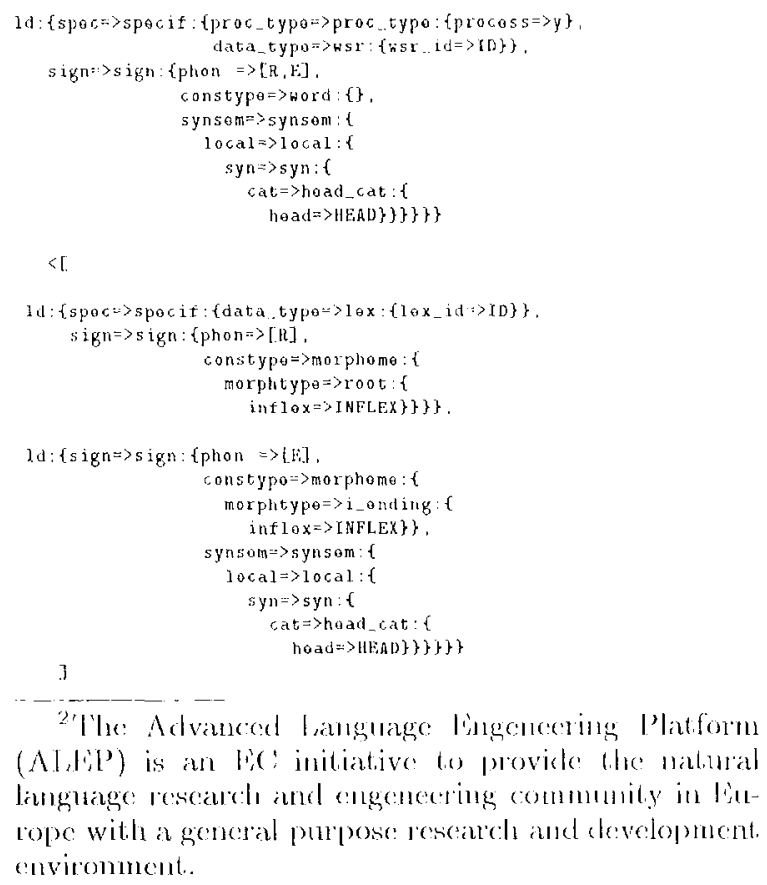

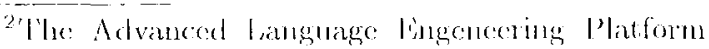
(Aletil) is an be iniliative to provide the natual lenghage reseand and engenecting community in liturope with a general purpose reseated and (levelopment. enviromment.

'The rute is stated in tarditional norplemic terms: a) full worel cau be the mother node of a binary brauching structure whose daughters are a stem and an inflectional ending. 'The immediate dominance relationship is cxpressed by ' $<$ '. Danghless are listed belwen seplare backets, and separated by a comma in their precedence order. lionture structures are conclosed in curly brackets, and pathis are expressed through right-pointed arrows:

at. ribute: $=>$ value

Feature structures are hyped (Iless), with the type name separated by a colon:

l.ype_name: \{feature_structure\}

'The rule says that a stem and an infleclional ending combine in an inflected word form if and only if their INfilex 'Tless are mifiable. Although Italian morphology is treated hem as basically concatenative, the formal paradigm based apparatus we propose here can vaniously be couched in either process-based or morphentebased morphologies, the choice betwen the two being dictated only by empirical considerations concerning the mainly concatenative or nonconatenative nature of thre language in culustion (Mathews 1974, Calcler 1989).

\section{The Morphological Lexicon}

'The AlliP' Italian morphological lexicon includes two basic entry types, stcms and inflectional endings, both structured paradigmatically. $\Lambda$ thind l.ype, covering all non inflecting itens, will not be considered here.

A verb entry is concoded aceording to an appropriate indexing schema which conforms to Gile: In particular wo use some Alipl macros such as the following:

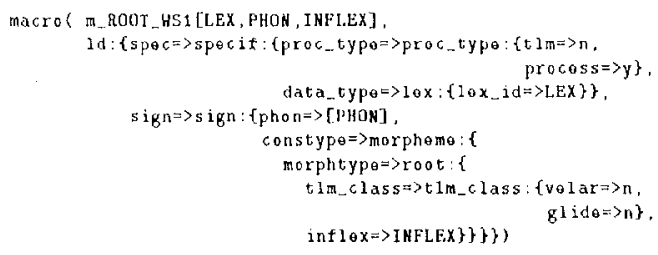

'T'he MIROO'T_WSI mareo takes thee argunentis (between square brackets in the first line of the macol: LWX, which specifies the encoded lexeme as a value of the attribute 'lex.id', P'IOON, a possibly singleton list of the stem alternants of the loxene in gucstion, and INlibiX, which, among other things, enfores the relevant stem indexing schema. An instantiation of the arguments of this macro spells out the following lexical entry of the irregular verb SCHNDERL' ('got down'): 


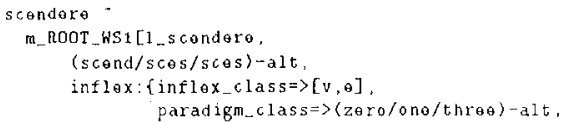

where IJAX is instianted as 'Iscendere' PHON is assigned two stoms (scend- and sace-), and INflatex takes a disjunctive list of paraligmatic: indices which roredate with l.he PlaON values through the formal device known as named disjunction (Kriegel and Nerbonme 1991). Named disjunctions are disunctive lists of chements enclosed in brackets and separated by a slash. An elementi of a named disjunction can, in its torn, be a (named) disjunclive list. A namo is separated by its list through a cash

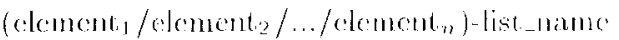

The eloments of two identically named disinnetions (ceg. -alt.) are made covary in their respecetive order. Accordingly, sece- is assoriated with ej-

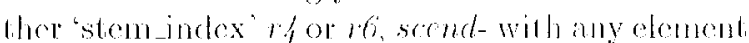

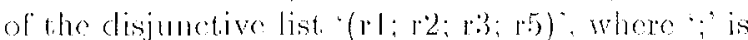
the OR operator. Stom indiess are also refereed to their relevant inflectional endings through covari ation with the values of "paradigmedass'. which defines the set of appropriatio inflectional colings, and corresponds roughly to the notion of conjugalion class.

A paraligmatic schema is encoded as a complex entry of type "inflectional encling" whose pron coutains a disjometive list of paradigmaticallyrelated endings. 'This is dono by using the matero below, which takes one more argmonent than the

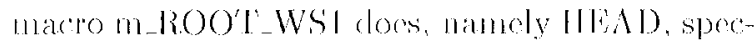
ified for antegory, agrecment. and tensomood information.

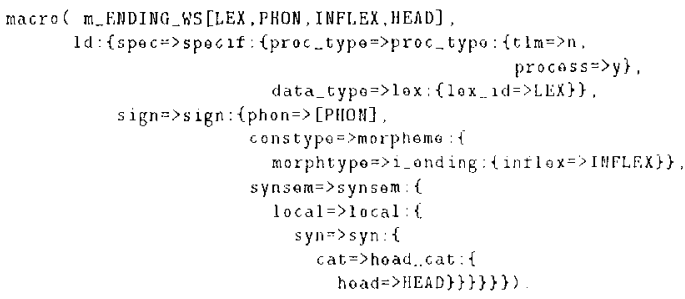

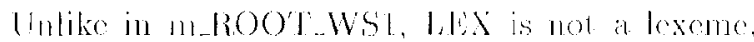
but a particulas tersemood sperilication; o.g. present inclieative in the example below:

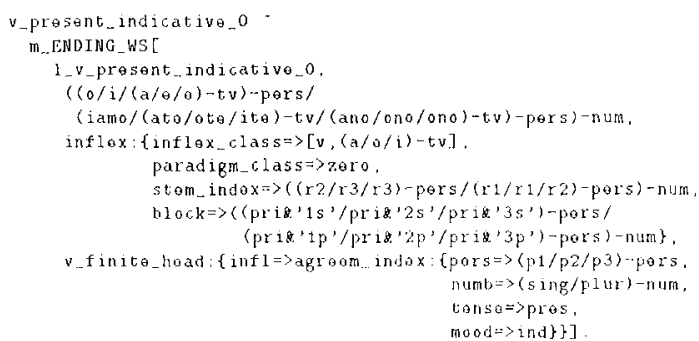

Stem indices correlate with the set of inflestional cndings (for the present indicative of 'paradigm_lass' zero) with which they can occur. The INFLEX argument contaius, besides paradigm class and paradign schema infomation, the feature 'block', whose main pupose is to stop defective verbs from being inflected for particular paradigm cells.

In compliance with GIC, the same paradigmatic schema is used for capturing distributional tedundancies in the selection of alternating as woll as non alternating stems. For example, the entry of the regular verb amare below is makle unify with the paradigmatic schema above through WTR. with no further readjustment: its uniquestem am, Ieft lexically umspecified for paradigmatic indexing, unifies with any index.

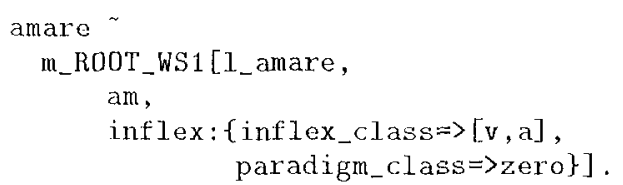

\section{The Italian Paradigm Schema}

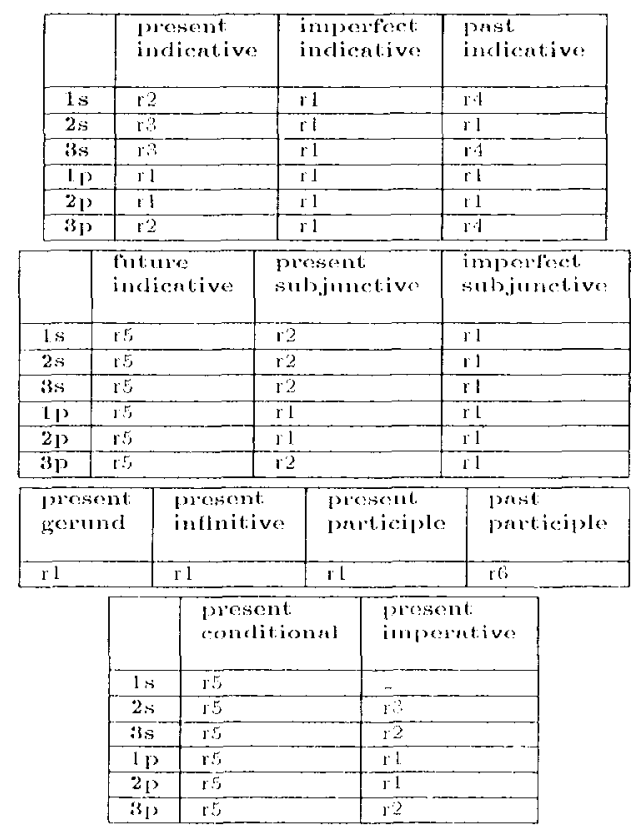

The schema above works with a fully expanded version of cile:, where default indexing for alternants r.4-r6 are conveniently stipulated. 'The' schema acounts for all regular Italian verbs of any conjugation class and for the vast majority of talian irregular basic and inchoative verbs, approximately 150 lexemes.

In the end, it fails to accombt for 1 irregular verbs of the first conjugation elass (namely andare, dawe, fare, stare) only, and six irregular verbs of the second and thind conjugation (avere. 


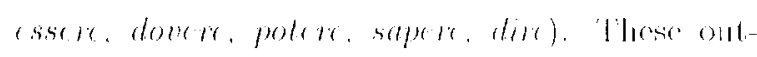

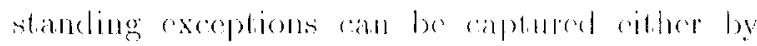

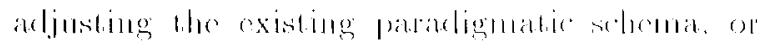

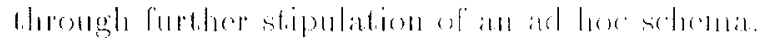

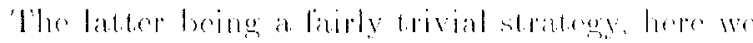

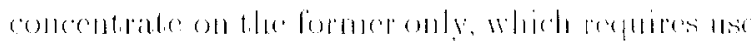

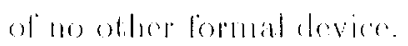

All ten outstanding exceptions stater the prop.

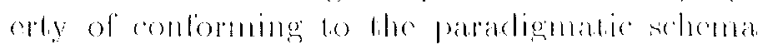
above only partially. A geod example is the present indicative of 1 (o)

\begin{tabular}{|c|c|c|c|c|c|}
\hline $11 \%$ & . & $n / m m \cdots "$ & & 1 & i? \\
\hline$d e n$ & i & 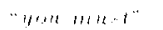 & & 2 & $1:$ \\
\hline$d \cdot d$ & , & 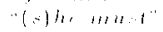 & & $\because$ & 16 \\
\hline (w) he & (x)m, & "w, mu:- & 1] & 10 & 11 \\
\hline$d i, \cdot$ & . & "yons man-l" & & 2 & ij \\
\hline a. & $m$, & "then matel" & & 1 & $?$ \\
\hline
\end{tabular}

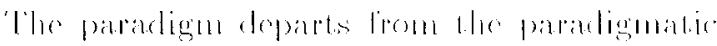

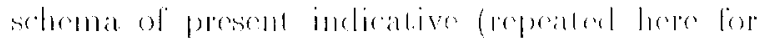

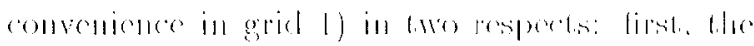

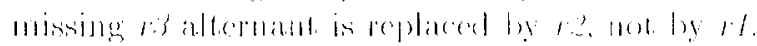

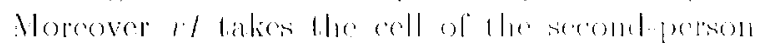

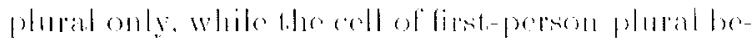

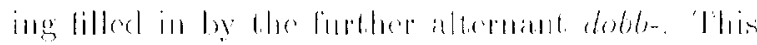

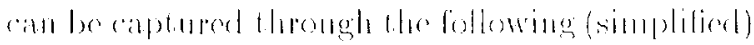
lexical entry of oovelisti:

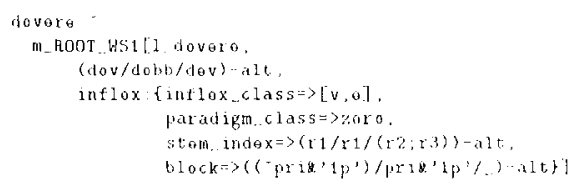

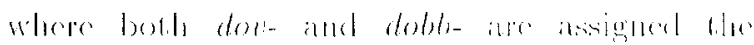

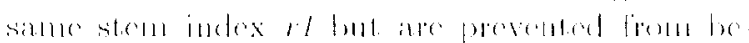

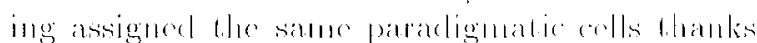

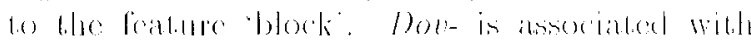

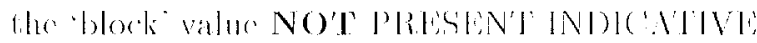

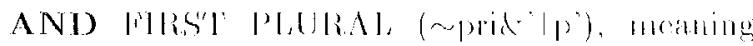
that dou- is bocked from showing ap in that

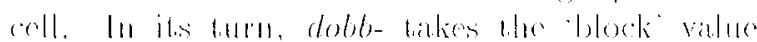

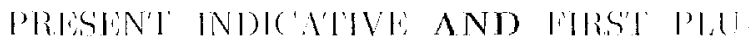

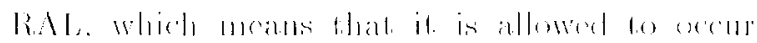

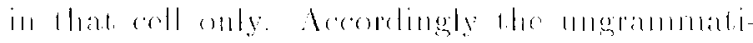

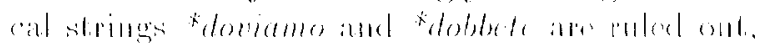

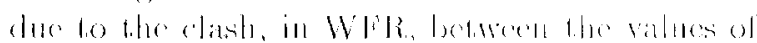

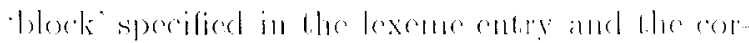
responding values of an inflectional ending.

\section{Discussion}

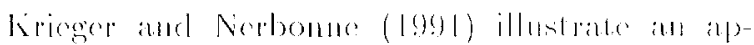

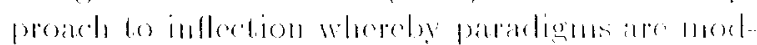

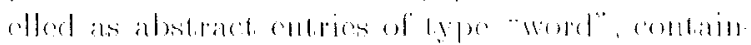

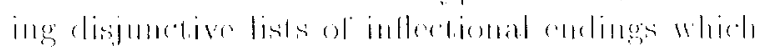

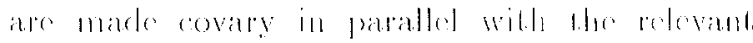

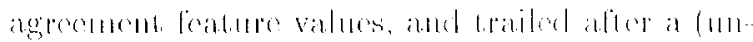

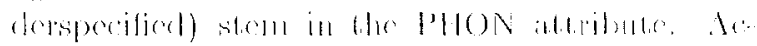

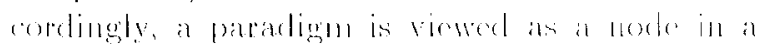

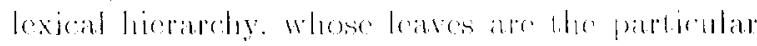

lexical entries which inherit the paralign of their mother node. Moreover, no paradignatic selenema is resorted to. However ancephlually neat, his apploach is not implementable in a momotonic formations such as Aldile, where defante inbert-

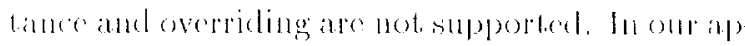

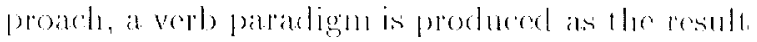

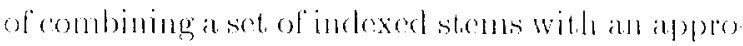
priate classis of inflectional endings through a single

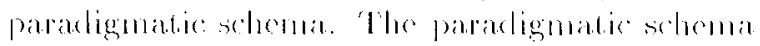

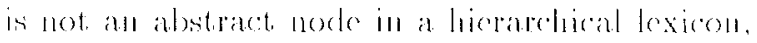
hut a (namod) dinjunetive list of fully-sperefied en fres of type "inflectional endeling", cach compenting with the others for one or more specelie reslls) in

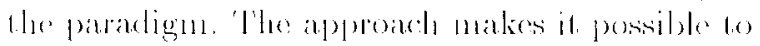
cluster vorbs in compalativoly low, lighty natu-

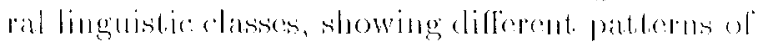
stem indexing, with a comparatively scanty repertoire of formal means (no nommonotic operations being resorled to). Among other things. it sim-

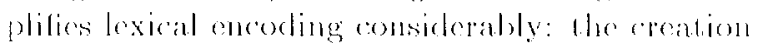

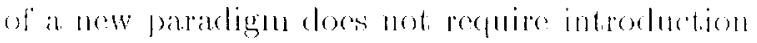

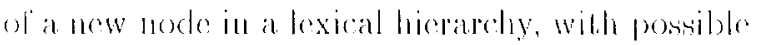

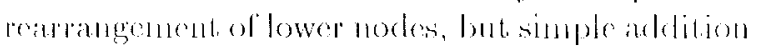

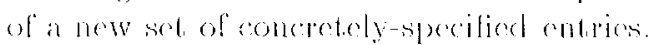

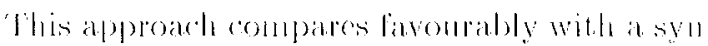

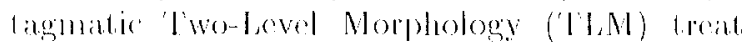
ment. of paradigmalice stom allermants soon as instances of phonologieally conditioned supplotiont.

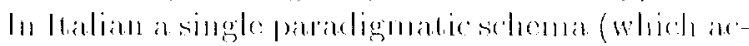
counts, hegenther with (ilc! for all regulat werls

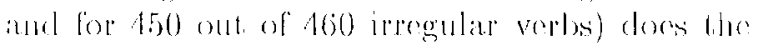

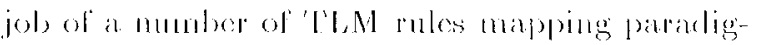

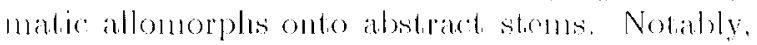
not all stem allicrtantwe need be indexert in the loxiron. Somo of them, refored to as syntagmatic stem altermants in the literatare (Stmmp 1995), are treated as genume instanes of phonologienally conditioned suppletion, and thus taken are of by

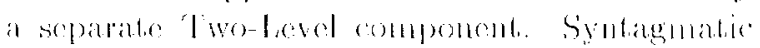
stemo allermants which, molike paradigmatio ones. coecur in llatian with both regulas and imegulas verbs, are not considered findituer here

finally, it is worth noting that the propesed paradignaticapproach works in generation as well as in analysis at no adelitional computational cost.

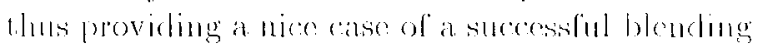
of descriplive ecomomy and dedarabivity.

\section{Inprovements and conclusion}

Gile makes referenee log posilional values in the

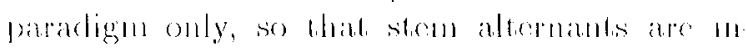

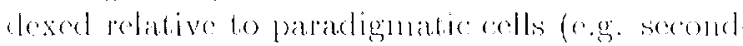
person singular of present indiatilive), not to in herent formal properties enther of hecies or of the 
inflectional endings, in kepping with IAIL. In the current implementation, all stem alternants of a certain vert) are indexed, within the relevant lexical cotry, in pracsentia, that is through full listing. so we miss the generalization that the same type of stem alternation takes place in more than one

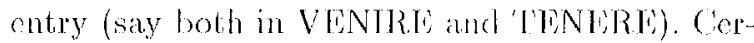
tainly, a more highly valued lexicon should also be able to capture this redundancy. Within the approach suggested here, an casily imagined solution is that the lexical value of redundant stem alternants is abstracted away from any such redundant properties, which are stored in a separate "melat entry". Full texieal chtries are then cranked out through unification of these separate pices of information, a root alternant such as veng-being thus produced thengh concaticnation of 1 - and -eng-. However simple, this solution is impossible to implement in ALLP, where a string undergoing lexicon look-up is always an atom (as opposed to a lisb). With a parsimonious use of formal means, it can nonetheless be implemented in livans and Gazdar's DA'TR quite straightforwardly (Lvans and Gazdar 1900), 1995).

By way of conclusion, our experience shows that: i) the inflectional morphology of Italian is an inventory of both internally- and externallyrelated paradigms rather than an inventory of unrelated morphenes; ii) paradigns define highly natural inflecting classes; iii) if looked at, at an appropriate level of abstraction, lhoy exhibit a strikingly uniform and simple underlying pattern of stem distribution: the paradigmatic schema; iv) a paradigmatic schema is declarative, and works well in both word analysis and generation; it relies on a minimum of word structure rule stipulation; v) it allows for a considerable level of descriptive conony: in lialian a single sehema (in combiuation with Glo) is found to hold for all regular verbs, and for 150 out of 160 irregular verbs; vi) it cau be ignored only at the fairly ligh price of writing a good many ad hoc readjustment rules; vii) finally, it is not computationally greedy; it can be implemented even in lean monotonic frameworks such as $A \mathrm{~L}$ liP.

(*) All ideas of this paper are the ontcome of a joint, effort: for the specific concerns of the Italian Academy only, V. Pirrelli is responsible for sections 1, 2, 6 and 7. M. Battista for sections 3, 1 and 5.

\section{References}

Battista Marco, Vito Pirrelli, 1905. The Treatment of Italian lnflectional Morphology using a Pyped lieature Structume Formalism. Final Report of MJ.AP 93-08b project (Constraint-Based linguistic: Specifications of [talian, COLSI'T), WP2.

Battista Marco, Vito Pirrelli, Nilda Ruimy, 1095. Italian Inflectional Morphology [nplemented in the Als' framework: a Paradigm-Sased Approach. Deliverable Tr-D5-IT of LSGRAM (Large scale Grammar) project, li-WP?

Galder Jo, 1989. Paradigmatic Morphology, in Procecdings of $A C l$, Mauchester.

Carstairs-McCarthy Andrew, $1988 . \quad$ NonConcatcnative Inflection and Paradigm Economy, in Hammond M. and Nooman M. eds, Theoretical Morphology: Approaches in Modern Linguistics, pp. 71-77, San Dicgo: Academic: P'ress.

Carstairs-McCarthy Andrew, 1992. Current Morphology. London: Routledge.

Carstairs-McCarthy Andrew, Joseph Paul Stcmberger, 1988. A Processing Constraint on Infleclional Homonymy, in Linguistics 26 , pp. 601-617.

Cray Systems, 1994. WT-6/1 Iinguistic Formalism. ALLP Documentation, Luxembourg.

Evans Roger, Gerald Gazdar, 1990. The J) ATTR Papers. Cognitive Science Research Paper 139, University of Sursex.

Evans Roger, Gerald Gazdar, 1995. DATR: A Language for Lexical Knowledge Representation. Cognitive Science Reseach Paper 382, University of Sussex.

Krieger Fans Ullrich, John Nerbonne, 1991, l'catureBased Inheritance Networks for (omputational Lexicons, in Procedings of the Acquilex Workshop on Default Inheritance in the Lexicon, Cambridge.

Matthews Peter lfugoe, 1992, Morphology (second edition). Cambriklge University Press.

Pirrelli Vito, 1993. Morphology, Analogy and Machine Translation. Phd Dissertation, Salford Jniversily, UK.

Pirrelli Vito, Stefano Pederici, 1994. Derivational Paradigms in Morphonology, in Procesdings of Col. ing, Japan.

Spencer Andrew, 1988. Arguments for Morpholexical Rules, in Journal of linguistics 2.4, pp. 1-20.

Stump Gregory, 1991. A Paradigm-Based Theory of Morphosemantic Mismatches. Language $6 \%$

Stump Gregory, 1995. Stem Formation, Stem Indexing, and Stem Choice. Unpublished Manuscript.

Wurzel Wolfgang Ullrich, 1989. Inflectional Morphology and Naturalness. Dordrecht: Reidel. 